\title{
THE END OF THE LATE ANTIQUE FORT IN LOBOR AND THE BEGINNING OF THE SLAVIC SEIZING OF PRESENT-DAY NORTHWESTERN CROATIA
}

\author{
Krešimir Filipec
}

DOI: 10.17846/CL.2017.10.2.23-34

\begin{abstract}
FILIPEC, Krešimir. The End of the Late Antique Fort in Lobor and the Beginning of the Slavic Seizing of Present-Day Northwestern Croatia. During the turbulent Migration Period, the late antique population of Roman provinces sought protection in easily defendable prehistoric hillforts that had been previously abandoned and such sites became the region's new centres. One of such forts has been investigated at the archaeological site of Majka Božja Gorska in Lobor. In the early decades of the 6th century, the fort experienced its construction peak and an early Christian church with a separate baptistery building was built. A cemetery was located around the church, with graves with inventory consisting of objects mainly associated with the late antique population and the Germans. The time when the Slavs occupied their new homeland is still very poorly explored, and the end of life of their predecessors, the late antique population and the Germans, can still be better tracked as opposed to the beginning of life of the new Slavic population. During the 9th century, Lobor would become one of the most important ecclesiastical and political centres of Lower Pannonia.
\end{abstract}

Keywords: Croatia, Lower Pannonia, Lobor, early Christian church, Christianization, 5th 11th centuries, churches

\begin{abstract}
Abstrakt: FILIPEC, Krešimir. Koniec neskorostredovekej pevnosti Lobor a začiatok slovanského zaujatia dnešného severozápadného Chorvátska. Počas turbulentnej doby stahovania národov hladala neskoroantická populácia rímskych provincií ochranu na lahko chránitelných miestach niekdajších pravekých hradísk, ktoré boli predtým opustené a takéto mesta sa stali novými regionálnymi strediskami. Jedno takáto pevnost bola skúmaná na archeologickej lokalite Majka Božja Gorska (Matka Božia Horská) v Lobore. V prvých desatročiach 6. storočia zažila pevnost' svoj stavebný vrchol a bol tu postavený včasnokrestanský kostol s oddeleným baptistériom. Cintorín bol situovaný okolo spomínaného kostola a prílohami v hroboch boli väčšinou predmety, ktoré môžu byt’ spojené s neskoroantickou populáciou a Germánmi. Obdobie, ked' Slovania obsadili ich novú vlast', je stále slabo prebádané, no koniec pôdobenia ich predchodcov, neskoroantickej populácie a Germánov, môže byt stále lepšie preskúmaný. To je v kontraste, ako bolo už uvedené vyššie, s poznaním začiatku života novej slovanskej populácie. Počas 9. storočia sa Lobor stal jedným z najdôležitejších cirkevných i politických cenier Dolnej Panónie.
\end{abstract}

Klúčové slová: Chorvátsko, Dolná Panónia, Lobor, včasnokrestanský kostol, kristianizácia, 5. 11. storočie, kostoly

Nowadays we can say that it is not unusual that we know so little about the beginnings and the first centres of the Slavs in southern parts of the Pannonian Basin during the 6th and 7th centuries. That is opposite to their role in later centuries, especially during the late 8th and early 9th 
centuries, and the rebellion of the Duke Ljudevit (Liudewit) in the first third of the 9th century. ${ }^{1}$ After the decades-long archaeological excavations, the situation is much better than it was before the 1990's, but there are still a lot of unknowns. Similar situation related to the state of research is not just characteristic for the Croats. It is common among other Slavic peoples, where it is also difficult to describe what happened in the time of the Great Migration pushes towards West and the Mediterranean. Much has been written on that topic in the last 30 years, and today, after more than a hundred years of dealing with this subject, we can say that we know much more about the late antique and the Great Migration Period traces related to the Germans than to the Slavs and the Avars (Sokol 1986, 54-60, 85-86, 104, 112, 114; Tomičić 2000, 142-163; Gračanin 2008 13-54; Gračanin 2011; Sekelj Ivančan 2010; Filipec 2015, 100-117). With these new immigrants the Great Migration Period ended in the southern parts of Central Europe and the Mediterranean. They formed the territory that we know today. Southern parts of Pannonia experienced the fate of the Roman provinces that had been abandoned by the Lombards after they had invaded Italy in 568 . But the problem of the Lombard migration and the dynamics of their leaving the Pannonian and Noric provinces is still not completely resolved. In the Croatian scholarship, it is generally believed that the path to the West and the Lombards' territory was opened for the Avars and their allies only after the fall of Sirmium (Sremska Mitrovica) in 582. Here we do not imply just the invasions and devastations happening before, in theory, ever since the time of the Gothic War in Italy, Dalmatia and Pannonia, about which the Split chronicler Thomas the Archdeacon also wrote. In one of the passages of his large historical work, he mentions the Slavs' invasion during king Totila's reign. This was a classic military occupation of the territory during which the fortified strongholds and settlements fell, and the newly arrived population settled the new territory (Filipec 2003, 117-143).

According to historical sources, it is relatively clear that the fall of major centres in PannonianNoric and northern Italian territories up to the river Isonzo (Soča) and Istria under the Slavic sway happened in the last decades of the 6th century (Celeia, Emona in 587, Teurnia, Aguntum in 591) (Ciglenečki 1987). That is completely confirmed and documented in historical sources that recount the final entry of the Avars and the Slavs into the Po Valley, from the direction of the present-day Slovenia towards Cividale. Historical sources have been confirmed by archaeology. The late antique hillfort settlement in Lobor, Majka Božja Gorska (Our Lady of the Mountains) in Hrvatsko Zagorje was abandoned, according to C14 analysis, around the year 580. A sample of the ashes was taken from the layer of the ruined early Christian church with a separate baptistery. The destruction and burnt layers are also visible on the wall and all around the site. We can clearly confirm that the entire settlement was burnt to the ground. Most likely this was the fate of many late antique fortified settlements in the wide area (Vranje near Sevnica in Slovenia, where a burnt layer has also been detected and associated with the destruction of the fort; possibly Rifnik, etc.). The abandonment of the Lobor site almost precisely coincides with the fall of Celeia that is documented in the historical sources. There are no visible traces of destruction on some late antique hillforts. Therefore one may divine that the population simply abandoned them. In theory, this might also be the case with the hillfort in Gornja Lonja, which is located close to the main road Siscia-Poetovio. What remains as a still opened question is whether these forts were destroyed in the Slavic attack or were burnt down by their late antique residents before they took the road to Italy. The late antique hillfort in Lobor, that had been a living centre in the previous period, especially in the first half of the 6th century, had, according to the archaeological finds, an unclear fate during the last decades of the 6th century. Only the rough pottery might provide a testimony for the last decades of the hillfort's life and use. The metallic finds, primarily

This work has been fully supported by Croatian Science Foundation under the project LearlyCop (IP-2016-06-6622). 
related to the cemetery close the church, cannot be dated after the mid-6th century, for example, a Varpalota Type S fibula. The resembling situation can only be detected at the borders of the extended Roman province of Dalmatia, where some of the outermost strongholds such as Sisak (Siscia) continued their existence, because they remained in the Roman hands. According to the archaeological material, ancient Siscia, along with the parts of Pannonia Savia on the outskirts of Dalmatia, was still out of the reach of the Avar domination in the first third of the 7th century. That means that, during this period, the limes along the river Sava still existed. Based on the rare historical and archaeological testimonies, it is to be expected that the Slavs' arrival in the province of Dalmatia happened at the beginning of the 7th century at the earliest, when the traces of the late antique culture, along with the elements of the Germanic culture, slowly started disappearing in the hinterland of the resisting strongholds along the eastern Adriatic coast and on the islands. The destruction of certain settlements and hillforts occurred even before that period, from the appearance of the Slavs approximately at the time of the Gothic War, and especially after the arrival of the Avars in the Carpathian Basin in 567/568. The rare historical sources are today increasingly being confirmed by archaeological investigations.

What remains open is an answer to the question of whether the Lombards defended their hinterland in the mountainous areas of Noricum and Pannonia, which they had not abandoned after their move to Italy or they handed the defence over to the Roman population? Despite the Lombards' move to Italy, some resisting strongholds in the western mountainous areas of Noricum and Pannonia seem to have remained in their hands. They seem to have tried to defend the territory at the doorstep of Italy that they held, most likely to slow or prevent the infiltration of the Slavs and Avars into Italy. Perhaps this is supported by some historical sources when recounting the fall of some towns. However, since the material evidence for the Lombards' presence in that period is lacking, it may be that the remaining late antique population in the hillfort settlements refused to leave their homeland. This territory, on the border between Noricum and Pannonia, was occupied by the Lombards at the time of the Gothic War. It can be said that it was occupied just before the Lombards entered Italy in 568, and there was no reason to abandon this territory as it was obviously done with the eastern lowland territory. After the territory that belonged to the Gepids, and that, in general, coincides with the former Roman province of Pannonia Sirmiensis, was captured following the fall of Sirmium, there was a move to the West. Eventually, the Slavs and the Avars destroyed all hillforts and settlements that stood in their way towards the Po Valley. Thus they conquered the entire territory of western Pannonia and Noricum and moved into the parts of northern Italy up to the river Isonzo. Especially when it comes to the parts of present-day Croatia, there is still not sufficient archaeological evidence to tell how much of the old population stayed in the area. Archaeological finds from the Lobor hillfort do not indicate that the life had been restored in any form immediately after the destruction of the hillfort. Thus we may conclude that the hillfort was completely abandoned by the old inhabitans who had never returned there. In Antiquity the Lobor hillfort had a significant role as a gathering hub for the local population and this is obviously why that the site had the same role after the establishment of the Carolingian rule.

The border between the Avar Khaganate and the Lombard Kingdom would remained almost unchanged around the river Isonzo within Italy until the collapse of the Avar state. More about how the material culture of the Slavs looked like has been recently learnt thanks to the discovery of numerous sites and settlements in the entire area between the rivers Sava and Drava and between the rivers Drava and Rába as well as in the mountainous parts of the present-day Austria, where the finds dating from the first migrational wave in the late 6th and, more likely, the early 7 th century have been unearthed. Thus it has been established that one may expect to find the Slavic settlements all across these areas, in general, where the traces of earlier culture layers have been 
recorded, particularly along important roads and in fertile valleys and fields. The finds become more numerous towards the second half of the 7th century and in the 8th century.

Today some conclusions may also be drawn about the Slavic cemeteries in southern Pannonia, even though only three such cemeteries have so far been certainly established in the area of present-day northern Croatia (Vinkovci, Belišće and Lobor), next to the uncertain and dubious ones that had been discovered previously (Sekelj Ivančan - Tkalčec 2006, 141-212; Filipec 2009, 27-30; Vinski 1954, 71-82; Tomičić 2002, 129-141). Each of the mentioned three cemeteries testify, in their own way, to the graves' appearance and difficulties related to such research. Next to the urn burial, which was recorded on all three sites, the graves with no urns were also discovered. They are incineration graves where handmade earthenware vessels, along with those made on pottery wheel, have appeared. Apart from the urn burial, the simple earth-pit burials with no urns have also been recorded. All grave pits were very shallowly dug, particularly in the Belišće-Zagajci cemetery in the part of Slavonia along the river Drava (at the border between the agri of Mursa/ Mursella and Sopianae). Such situation has also been recorded in Lobor, where one urn has been unearthed, but pits have also been discovered during archaeological excavations that only contained filling and nothing visible in terms of archaeological artefacts, or only small fragments of pottery vessels have been found, which could be related to the remains of a settlement. Small bone particles have not been preserved for the most part due to the intense acidity of the soil. The incineration cemetery in Lobor is specific in relation to other cemeteries discovered close to the ancient agglomerations or in fields due to its location on a late antique fort, and in the fort's best section where two churches stood in previous times. The fort's significance is based on that it was not only an important centre for the local population, but it was again reactivated during the 8th century, as the archaeological research has indicated so far, after it had been previously abandoned and destroyed. The fort is located in the mountainous and relatively protected area on the border between Pannonia and Noricum. Previously, the late antique graves with objects dating up to the mid-6th century have been discovered close to the church. The cemetery inside the fort shows much analogies with the similar situation in Vranje near Sevnica which was also destroyed in a fire (Petru - Ulbert 1975). A large octagonal baptistery testifies that this position had the significant drawing strength in Late Antiquity. The circumstances of the fort's fall coincide with what is known from historical sources.

The hillfort with the peregrination church of Our Lady of the Mountains is located to the northeast of the centre of the present-day municipality of Lobor, precisely above a narrow gorge leading across Ivanšćica Mountain (Filipec 2007, 411-422; Filipec 2010; Filipec 2013, 301310 ). Ivanšćica is almost completely inaccessible from three sides. On the north side, the hillfort was detached from the rest of the plateau, which is connected to southern slopes of Ivanšcica by a large earthen wall. The earliest discovered layers are dated to the Early Bronze Age, and there are also objects form the Late Bronze and Early Iron Ages. The most extensive construction works were undertaken in the late La Tène Period, when the plateau was organised, the wall built and various buildings constructed (the Early Iron Age). From the 2 nd century $\mathrm{AD}$ a new construction boom began. In the second half of the 5 th century a new construction boom began. In the second half of the 5th century or the early 6th century, the fort's new stone wall, various secular buildings, mostly wooden, and an early Christian church, properly oriented, with a separate baptistery building were built in a dominant position within the settlement. The church has been only partially explored, because a pre-Romanesque (9th century), a Romanesque (12/13th centuries) and a Gothic (14/15th centuries) churches were subsequently built over the early Christian church's central part. This single-nave early Christian church had a narthex and, on the north side, various adjacent rooms that were remodelled at different times. The northern wall of the church is about $17 \mathrm{~m}$ long and about $0.6 \mathrm{~m}$ wide, and the narthex is also approximately $17 \mathrm{~m}$ long. The church 
was entered through the narthex, i.e. through two side entrances. In front of the narthex, there was a corridor which connected the octagonal baptistery building. There was a hexagonal piscina inside the octagonal building $(6 \times 6 \mathrm{~m})$. The bottom of the piscina was lined with the floor marble tiles and the existing part of the Gothic church is also paved with the same kind of tiles, and thus it is not excluded that the early Christian church was paved with them too. The original concrete flooring of the baptistery building, a stair and a stone threshold into the corridor have been partially preserved. From internal inventory, one marble altar stone, which was set up later in the pre-Romanesque church, and a number of fragments of the window transennas, along with a large quantity of marble architectural sculptures, have been preserved. In the debris around the octagonal building, a very rustic statue of the goddess Diana, also made of marble, which was broken and thrown away at the time of the building's construction, has also been discovered. The finding of the statue speaks for the existence of an older ancient shrine at the same spot. Close to the church, several late antique graves have been discovered, which were mostly destroyed through later burials. Since the rare finds from the cemetery, mostly the chance finds connected to burials close to the early Christian church, date from about the mid-6th century, only a large quantity of pottery of everyday use testify to the fort's life until it was burnt down. No rebuilding layer has been detected after the fort's destruction, but burials of the new inhabitants in the late antique cemetery appeared to the south of the early Christian church. These new inhabitants burnt their dead and deposited their ashes in urns or in common pits (Filipec 2010, 347-357). Various fragments of pottery vessels and one incineration grave can be dated to the 8 th century. It is not excluded that, by then, the fort had already been reactivated and that a settlement existed inside, whose beginnings may be dated, solely based on the fragments of pottery vessels, to the 8th century at the earliest. Thus from the last third of the 6th century to the 8th century, there is no evidence for more than a hundred years that the fort had been inhabited. The fort would gain on importance after it had been incorporated in the Frankish realm. There is nothing to tell that the life of the earlier population had continued in any form, but it may be argued that elsewhere, probably among the descendants of the refugees to Italy, there remained a memory that an important ecclesiastical centre of an earlier time had existed on that spot.

In the early 9th century, the Frankish missionaries, probably the Benedictines, from northern Italy built a wooden building - a single-nave church with a rectangular apse and a canopy in front of the entrance. The nave with the apse measured about $11 \mathrm{~m}$ in length and about $6 \mathrm{~m}$ in width. Inside the church, there was a flooring partially made of clay mixed with rubble, and in front of the shrine in the church's interior, the holes for pillars are extant, probably remains of a wooden altar screen. During the 9th century, a cemetery of the Christianized population was formed, where the inhumation continued until the 19th century. Inside the wooden church, the bone fragments of the planking of a small wooden box, probably parts of a reliquary, have been discovered (Filipec 2010a, 51-59). Close to the wooden church and above the early Christian church, a preRomanesque church was erected, which had three inscribed apses, a vestibule and a bell-tower along the front through which the church was entered and another entrance on the south side. The sanctuary of the pre-Romanesque church partially incorporated the central sanctuary of the Romanesque church, and the central apsis of the pre-Romanesque church is still in part visible inside the sanctuary of the existing Gothic church, which had fully integrated the Romanesque apsis in the height of over two meters. A large quantity of most diverse stone fragments of architectural and ornamental sculptures dating from the 9th to 11th centuries has been found. The first altar screen, of which only several pilasters and plutei have remained, the church was given in the early 9th century, and a larger reconstruction happened in the second half of the 10th century. Of the pre-Romanesque fragments, very well-shaped pilasters, plutei, ambon, ciborium and two altar stones are noteworthy. A fragment of a transenna has been discovered, which contains a figure 
of a bearded man, most probably a dignitary who participated in the interior decoration of the church in the second half of the 11th century. Based on the discovered fragments with parts of the inscription, it can be assumed that the church's title was in honour of St. Mary, but St. Andrew, St. Ambrose or St. Anselm and St. Paul are mentioned, too, and Holy Trinity is probably also mentioned in the invocation. The pre-Romanesque church in Lobor had a number of titles, which was common in the early Middle Ages. The pre-Romanesque church in Lobor is for the time being the only pre-Romanesque church discovered in northern Croatia, and the richness of its interior ranks it among the most beautiful and richly equipped early medieval churches in Croatia.

In the end, we may only affirm that the late antique hillfort and settlement in Lobor opened, when it comes to the Pannonian-Noric area, questions that have been put forward many times: when did the life of the late antique population end and when did the new inhabitants settle their new homeland? It can be said that there are no traces of the remaining late antique population and that the Lobor hillfort was not occupied immediately after the newcomers arrived and captured the new territory. They seem to have had no use of the forts and they established, in fertile valleys and along the roads, settlements that were not fortified. The situation would change probably already after the mid-7th century, at the time of the crisis in the Avar Khaganate, and especially from the second half of the 8th century.

\section{REFERENCES}

Ciglenečki, Slavko. 1987. Höhenbefestigungen aus der Zeit vom 3. bis 6. Jh. im Ostalpenraum. (Dela SAZU 31). Ljubljana.

Filipec, Krešimir. 2010. Arheološko - povijesni vodič po svetištu Majke Božje Gorske u Loboru. Zagreb.

Filipec, Krešimir. 2013. Aquilean missionary center in the Frankish lower Pannonia the turn of 8th in 9th century. In Hortus Artium Medievalium - Journal of the International Research Center for Late Antiquity and Middle Ages 19, 301-310.

Filipec, Krešimir. 2003. Kasnoavarski ukrasni okov (falera) u obliku veprove glave iz Siska. In Godišnjak Gradskog muzeja Sisak 3-4, 117-143.

Filipec, Krešimir. 2007. 10 Jahre archaologischer Grabung in Lobor (1998-2007). In Hortus Artium Medievalium - Journal of the International Research Center for Late Antiquity and Middle Ages 13, 411-422.

Filipec, Krešimir. 2009. Rani Slaveni u Belišću. In Zbornik 3 Grad Belišće - Muzej, 27-30.

Filipec, Krešimir. 2010a. Crkva u Loboru - najstarija franačka misionarska crkva u sjevernoj Hrvatskoj. In Starohrvatska prosvjeta III/37, 51-59.

Filipec, Krešimir. 2010b. Slavenski paljevinski grob iz Lobora. In Archaeologia Adriatica 3/1, 347-357.

Filipec, Krešimir. 2015. Donja Panonija od 9. do 11. stoljeća. Sarajevo.

Gračanin, Hrvoje. 2008. Slaveni u ranosrednjovjekovnoj južnoj Panoniji (Scrinia Slavonica) 8, Slavonski Brod, 13-54.

Gračanin, Hrvoje. 2011. Južna Panonija u kasnoj antici i ranom srednjovjekovlju (od konca 4. do konca 11. st.). Zagreb.

Petru, Peter - Ulbert, Thilo. 1975. Vranje pri Sevnici, Starokrščanske cerkve na Ajdovskem gradcu. Katalogi in monografie 12. Ljubljana.

Sekelj Ivančan, Tajana - Tkalčec, Tatjana. 2006. Slavensko paljevinsko groblje na položaju Duga ulica 99 u Vinkovcima. In Prilozi Instituta za Arheologiju u Zagrebu 23/1, 141-212. 
Sekelj Ivančan, Tajana. 2010. Podravina u ranom srednjem vijeku. Rezultati arheoloških istraživanja ranosrednjovjekovnih nalazišta u Torčecu. Monographiae Instituti archaeologici 2. Zagreb.

Sokol, Vladimir. 1986. Područje sjeverozapadne Hrvatske između 400. i 800. godine (Velika seoba naroda). In 40 godina arheoloških istraživanja u sjeverozapadnoj Hrvatskoj. Koprivnica, 5460, 85-86, 104, 112, 114.

Tomičić, Željko. 2000. Arheološka slika ranoga srednjeg vijeka na prostoru međurječja Drave, Dunava i Save. In Milošević, Ante (ed.): Hrvati i Karolinzi. Rasprave i vrela. Split, 142-161.

Tomičić, Željko. 2002. Keramika iz (ponekih) ranosrednjovjekovnih grobalja kontinentalnog dijela Hrvatske. In Guštin, Mitja (ed.). Zgodnji Slovani, Zgodnjesrednjeveška lončenina na obrobju vzhodnih Alp, Ljubljana, 129-141.

Vinski, Zdenko. 1954. Gibt es frühslawische Keramik aus der Zeit der südslawischen Landnahme? In Archaeologia Iugoslavica I, 71-82.

SUMMARY: THE END OF THE LATE ANTIQUE FORT IN LOBOR AND THE BEGINNING OF THE SLAVIC SEIZING OF PRESENT-DAY NORTHWESTERN CROATIA. According to historical sources, it is relatively clear that the fall of major centres in Pannonian-Noric and northern Italian territories up to the river Isonzo (Soča) and Istria under the Slavic sway happened in the last decades of the 6th century. That is completely confirmed and documented in historical sources that recount the final entry of the Avars and the Slavs into the Po Valley, from the direction of the present-day Slovenia towards Cividale. Historical sources have been confirmed by the archaeology. During the turbulent Migration Period, the late antique population of Roman provinces sought protection in easily defendable prehistoric hillforts that had been previously abandoned and such sites became the region's new centres. One of such forts has been investigated at the archaeological site of Majka Božja Gorska in Lobor. The fort was built close to one of alternative road routes connecting two important centres - Siscia (Sisak) and Poetovio (Ptuj). In the early decades of the 6th century the fort experienced its construction peak and an early Christian church with a separate baptistery building was built. A cemetery was located around the church, with graves with inventory consisting of objects mainly associated with the late antique population and the Germans, probably the Lombards who held that position with the permission of the Roman government after the demise of the Gothic state. The majority of finds comes from graves and layers destroyed due to the position's long and continuous use. In 580's, after the Lombards' invasion of Italy had already started, the fort was destroyed, i.e. burnt down. The burning down of the fort, due to which the late antique population ceased to inhabit that position, is the only evidence of the first wave of the Slavic conquest of the region. The time of the fort's destruction may be approximately connected to the Slavic invasion of Italy that is documented in historical sources. The youngest archaeological objects and graves indirectly testify to that. Following an almost continuous one-thousand year long life of the old Pannonian-Norican population in Lobor, there was a radical population change. The new immigrants, the Slavs, needed not the old forts or dilapidated buildings within the forts, since these were located on not easily accessible positions, far from fields and pastures. The forts had remained completely abandoned for almost two centuries. Only around the mid-8th century, presumably at the time of the changed political circumstances and the FrankishAvar conflict, the forts started being used again, as evidenced by a Slavic cremation cemetery and the Carolingian architecture, cemetery and objects during the 9th century. The time when the Slavs occupied their new homeland is still very poorly explored, and the end of life of their predecessors, the late antique population and the Germans, can still be better tracked as opposed to the beginning of life of the new Slavic population. During the 9th century, Lobor would become one of the most important ecclesiastical and political centres of Lower Pannonia. 
Krešimir FiLIPEC

Krešimir Filipec

University of Zagreb

Faculty of Humanities and Social Sciences

Department of archaeology

Ivana Lučića 3

HR-10000 Zagreb

Croatia

kfilipec@ffzg.hr 
The End of the Late Antique Fort in Lobor and the Beginning of the Slavic Seizing of Present-Day NORThWESTERn Croatia

\section{Appendix/Prílohy}

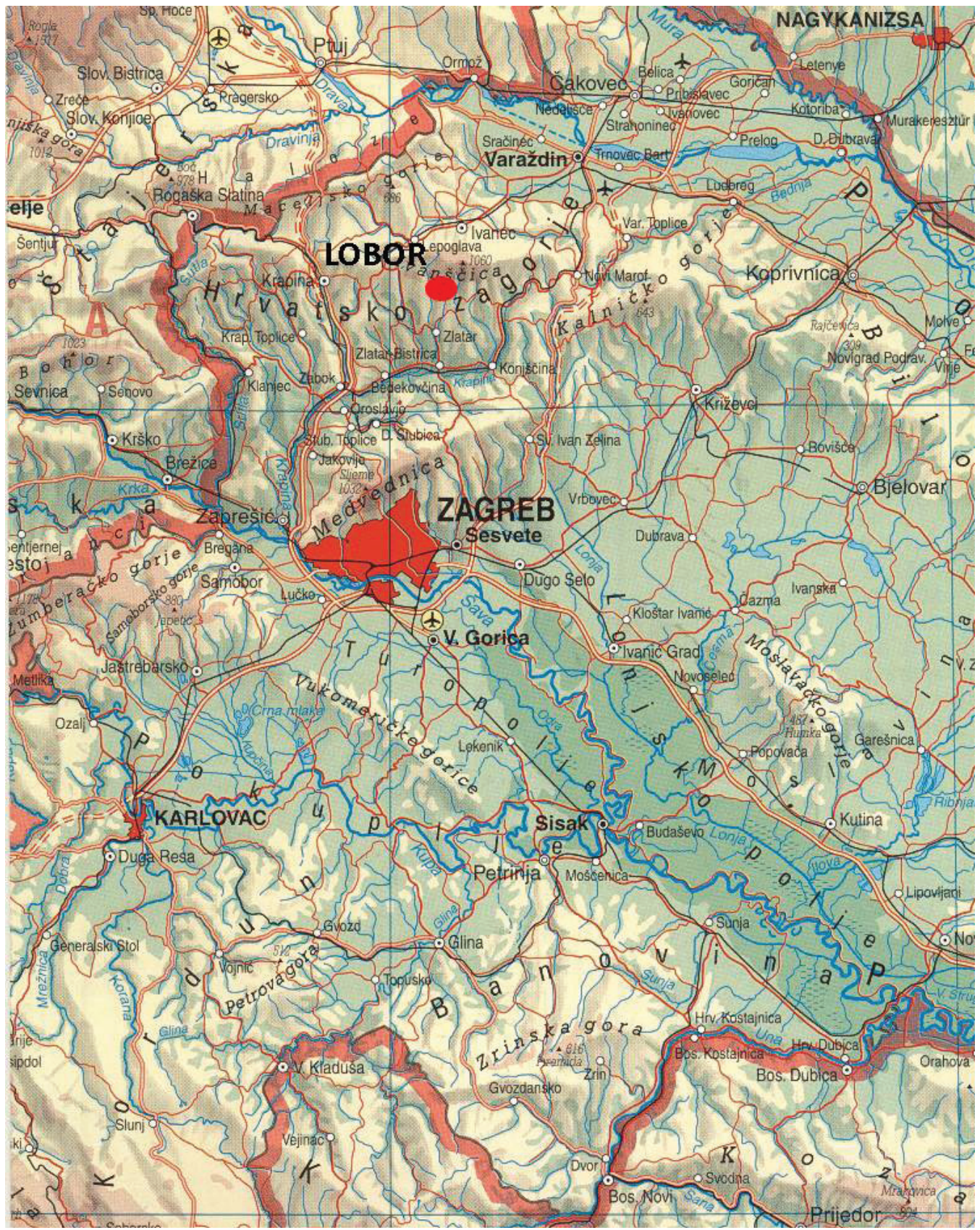

Fig. 1. Position of Lobor on the geographic map. / Obr. 1. Pozícia Lobora na geografickej mape. 


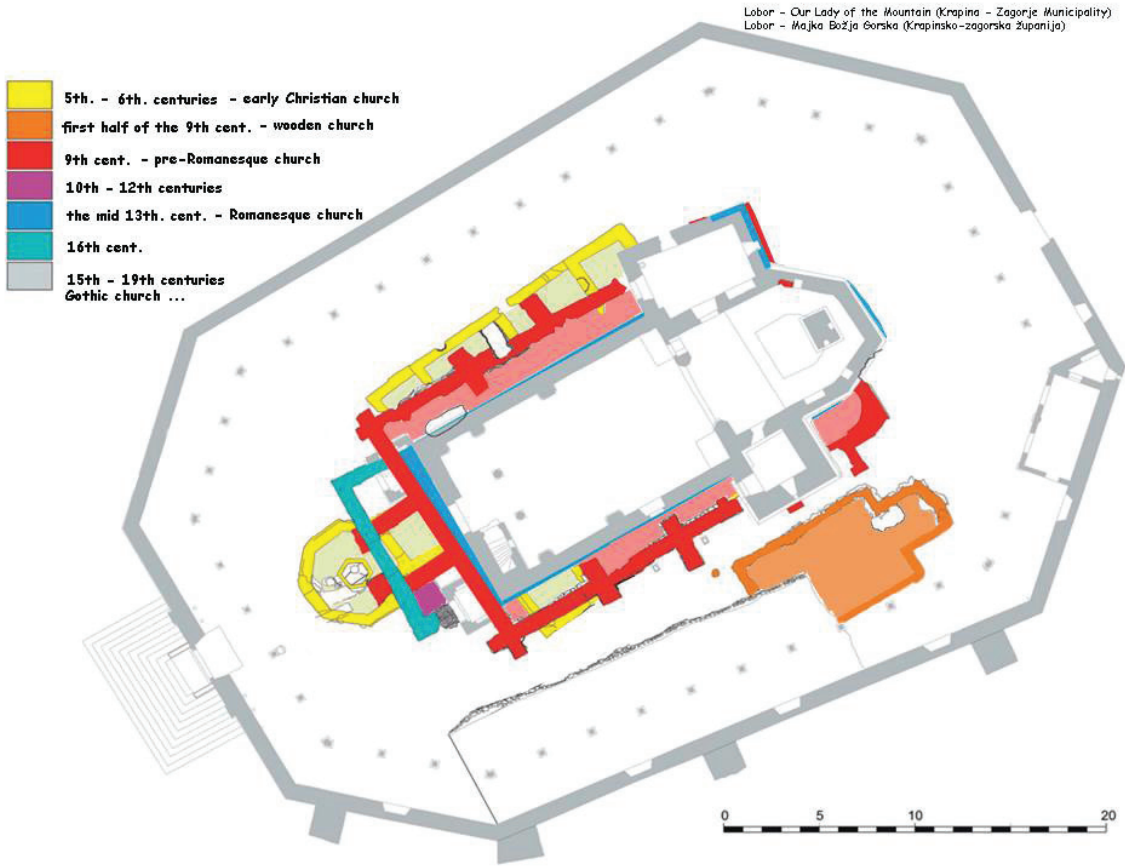

Fig. 2. Lobor, ground plan (Krešimir Filipec). / Obr. 2. Lobor, plán pôdorysu (Krešimir Filipec).

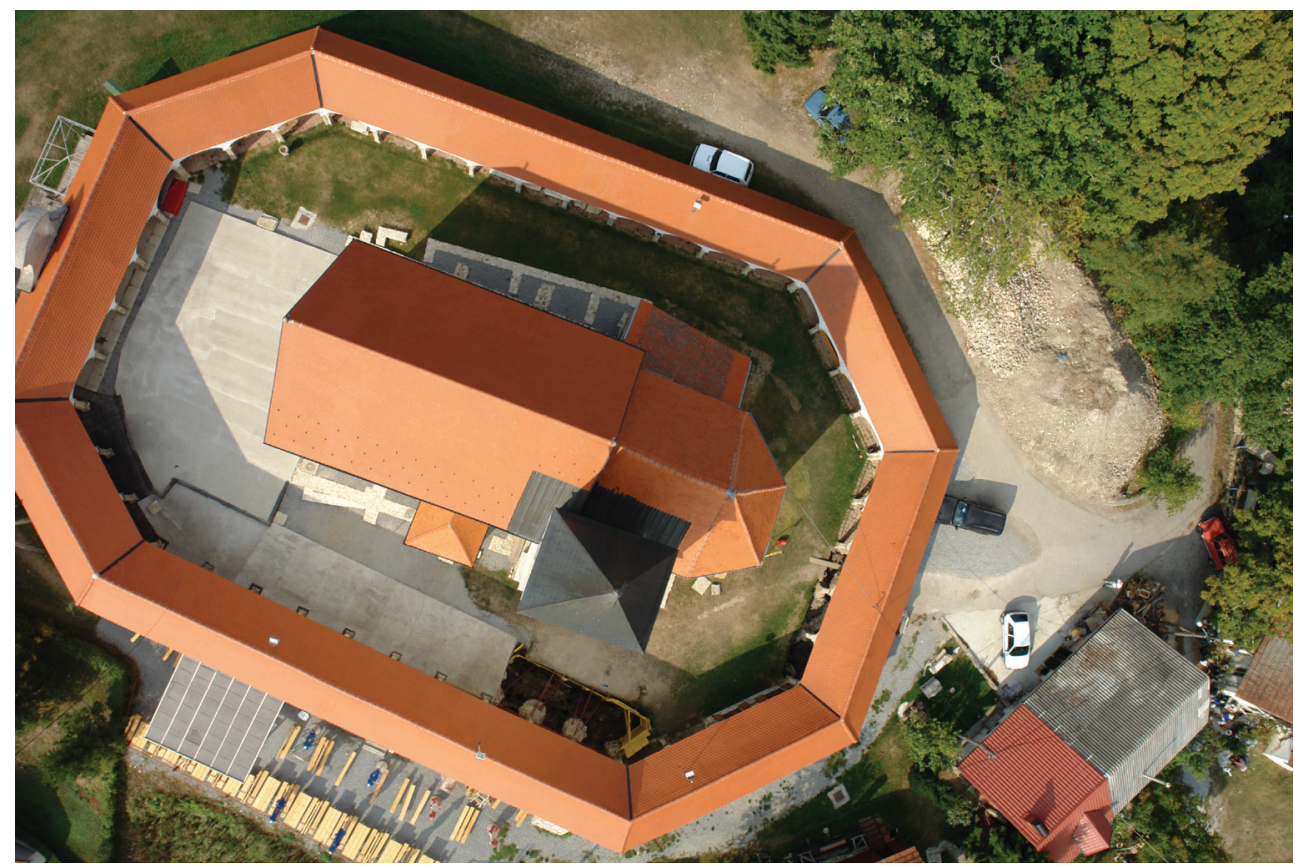

Fig. 3. Church Our Lady of the Mountains (Crkva Majke Božje Gorske). / Obr. 3. Kostol Matky Božej Horskej. 


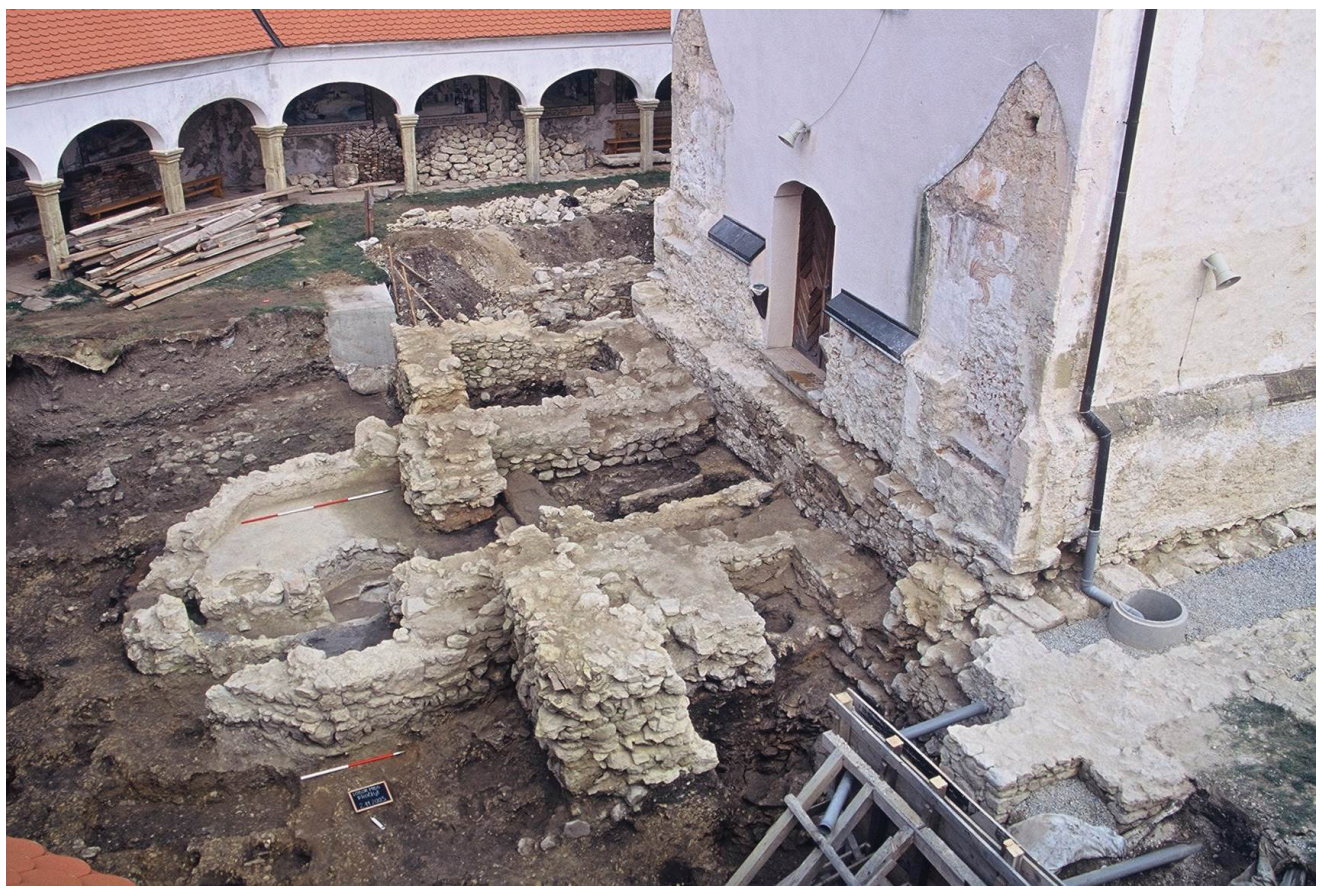

Fig. 4. Archaeological excavations around the church of Our Lady of the Mountain in 2005. / Obr. 4. Archeologický výskum okolo kostola Matky Božej Horskej v roku 2005.

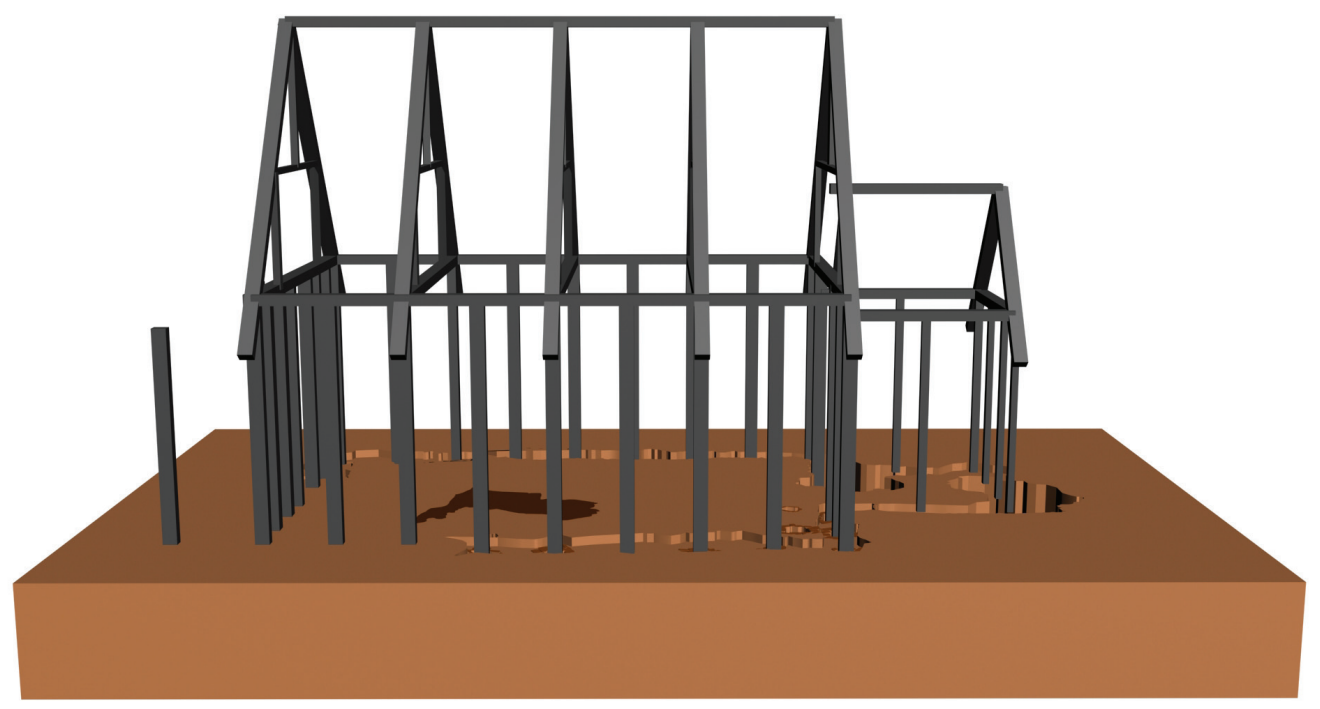

Fig. 5. Reconstruction of the wooden church (draft), the 9th century. / Obr. 5. Rekonštrukcia dreveného kostola (náčrt), 9. storočie. 
KreŠIMIR FILIPEC

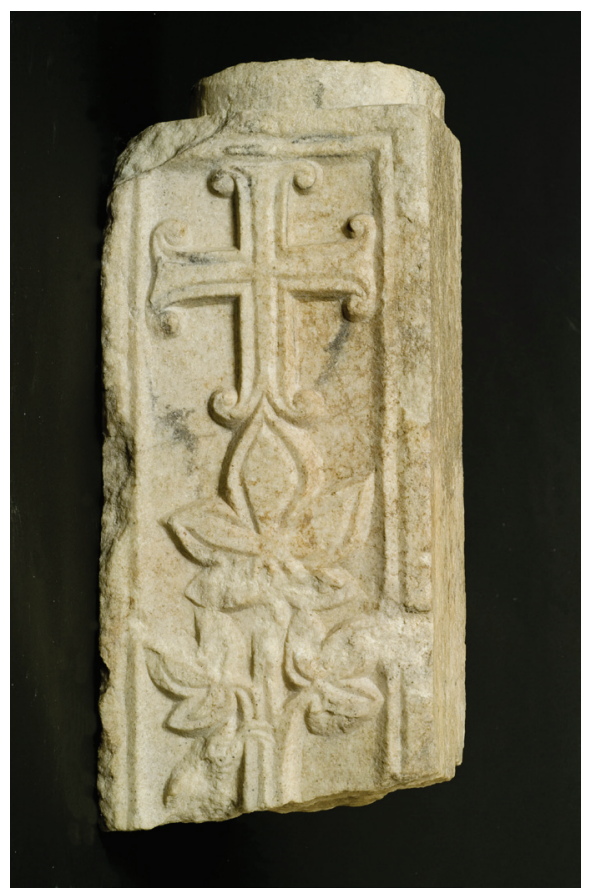

Fig. 6. Pilaster of the pre-Romanesque church, the 9th century. / Obr. 6. Pilaster predrománskeho kostola, 9. storočie. 